\title{
EXPERIMENTAL INFECTION WITH SCHISTOSOMA MANSONI OF BIOMPHALARIA STRAMINEA FROM DIFFERENT PARTS OF THE NORTHEAST OF BRAZIL.
}

\section{S U M M A R Y}

In the western part of the State of Bahia Biomphalaria straminea and $\mathbf{B}$. glabrata both occur, but in the majority of cases they do not share the same habitat. In the State of Ceará, however, B. straminea is the sole snail host of Schistosoma mansoni. In this survey, no naturally infected B. straminea was found among snails collected from Bahia and Ceará, evidently because of the very low infection rates. The susceptibility of laboratory-reared specimens to infection with a Puerto Rican strain of $\mathbf{S}$. mansoni was then tested experimentally. In general, the snails showed very low susceptibility. The infection rates were $1.1 \%$ among snails from Redenção (Ceara); $2.3 \%$ in those from Pentecoste (Cear rá); $2.9 \%$ in snails from São Desidério (Bahia), while they were very high among an albino strain (NIH) of B. glabrata used as control. Another group of B. stra minea from São Desidério was exposed to a Bahian strain of $\mathbf{S}$. mansoni and the infection rate was still very low (3.6\%) Apparently, the very low susceptibility of B. straminea, despite high snail density, is correlated with moderate infection rates with $\mathbf{S}$. mansoni among humans, as shown by the results of stool examinations conducted by SUCAM in the municipalities of Redenção and Pentecoste, in Ceará.

KEY WORDS: Schistosoma mansoni: Experimental infection - Snails Biomphalaria straminea - Northeast of Brazil

\section{N TROD U GTION}

In the northeast of Brazil two species of Biomphalaria, viz. B. glabrata and B. straminea are intermediate hosts of Schistosoma mansoni. B. glabrata is present in the coastal area and the adjacent regions of the interior. It is found in several localities in the states of Pernambuco, Alagoas, Bahia, Rio Grande do Norte, Paraiba and Sergipe. B. straminea has a wider distribution, and there are numerous habitats in Ceará. Rio Grande do Norte, Paraiba, Pernambuco, Alagoas and Bahia, and a few scattered habitats in Piaui and Sergipe. In the State of
Ceara, B. straminea is the only biomphalarid species present and is, accordingly, the sole intermediate host of S. mansoni.

It has been shown that in the State of Pernambuco B. glabrata is a more efficient snail host in the field than B. straminea, and that under laboratory conditions B. glabrata is much more susceptible to infection with $\mathbf{S}$. mansoni than is B. straminea (BARBOSA et al. 5; BARBOSA \& COELHO 3 ; COELHO \& BARBOSA ${ }^{10}$ ). In the State of Ceara, BEZERRA ${ }^{8}$ showed that natural infection with $\mathbf{S}$. mansoni in $\mathbf{B}$. straml. 
MALEK, E. A. \& ROUQUAYROL, M. Z. - Experimental with Schistosoma " mansoni of Biomphalaria straminea from different parts of the northeast of Brazil. Rev, Inst. Med. trop. São Paulo, 28:160-165, 1986.

nea was very low. He found that one snail out of $1,228(0.08 \%)$ was naturally infected in the municipality of Pacoti On the other hand, ALENCAR ${ }^{1}$ stated that in one locality, also in Ceará, there was 0 to $27.2 \%$ infection among 307 B. straminea examined. Other data on natural infection of B. straminea with S. mansoni are: in the State of Pernambuco, 0 to $0.57 \%$ among 4,220 snails (COUTINHO et al. ${ }^{11}$ ); 0 to $0.64 \%$ among 4,345 snails from four localities (BARBOSA et al. ${ }^{5}$ ); $0.05 \%$ among 33,461 snails from 10 localities (BARBOSA \& COELHO ${ }^{3}$ ); $0.02 \%$ among 185,039 snails from 17 localities (BARBOSA \& COELHO $^{4}$ ); and $0.57 \%$ among 1,938 snails from one locality (LUCENA ${ }^{14}$ ). In the State of Para, PARAENSE ${ }^{18}$ found no infected snail among about 5,000 specimens examined. BARBOSA et al. ${ }^{7}$ found 0 to $0.055 \%$ infected among 51,435 snails examined in the State of Goias, and SOUZA et al.22 found no infected snail among 640 specimens collected in Minas Gerais

Only a few studies have been carried out on the experimental infection of $\mathbf{B}$. straminea, mainly in the states of Pernambuco and Minas Gerais. In the present study no naturally infected B. straminea were found among snails collected from Bahia and Ceará. Experimental infection of laboratory-reared snails from both states was then carried out to test their susceptibility to infection with two strains of $\mathbf{S}$. mansoni.

\section{MATERIALS AND METHODS}

Field collections of $\mathbf{B}$. straminea were made from the reservoir at Sāo Desidério, an artificial pond near Barreiras in western Bahia, and from irrigation canals at Pentecoste, and a stream at Redenção, both in Ceará. B. glabrata was collected in Bahia from a small stream above the reservoir at São Desidério and from banana plantation canals in Catolandia The snails were maintained separately in the laboratory in New Orleans, and several generations were obtained. Among B. glabrata collected in Catolandia there was a $\mathbf{2 4 . 5 \%}$ infection rate with S. mansoni. This strain of schistosome was maintained in white mice and was used in the experiments, in addition to a previously established strain from Puerto Rico, also maintained in white mice.

All B. straminea and B. glabrata snails used in the exposure experiments were laboratoryreared progenies of the field-collected snails. The snails, of all sizes (ages), were each exposed to 5 to 10 miracidia of the schistosome. Shell vials 13 to $16 \mathrm{~mm}$ in diameter were used in the trials. Exposure was carried out at room tem. perature $\left(23-25^{\circ} \mathrm{C}\right)$, and afterwards the snails were maintained in pans and plastic boxes. Va rious numbers of an albino NIH strain of $\mathbf{B}$. glabrata, or a pigmented $\mathbf{B}$. glabrata from a stream above the reservoir at São Desidério, were exposed under the same conditions as $\mathbf{B}$. stramines and from the same miracidial pool. Before exposure the snails were washed several times to remove oligochaetes and other microorganisms which might influence the results of the susceptibility tests.

\section{RESULTS}

Examination of B. straminea collected in the field in Bahia and Ceara proved that they were all negative for cercariae of $\mathbf{S}$. mansoni. There were 584 snails in 1974 , and 415 in 1975 , collected from the reservoir at São Desidério, and 172 from an artificial pond near Barreiras, in Bahia There were also 462 collected at Redenção and 288 at Pentecoste in Ceará in 1979. Among the snails from Redenção there were six infected with a strigeid trematode, probably a parasite of birds in the area; such forktailed cercariae emerging from some snails might b confused with those of $\mathbf{S}$. mansoni by an inexperienced laboratory technician.

In the experimental tests for the susceptibility of B. straminea the snails showed, in general, very low infection rates. Table 1 shows that the infection rates were $2.9 \%$ and $3.6 \%$ for snails from São Desidério using Puerto Rican and Bahian strains of $\mathbf{S}$. mansoni, respectively. The infection rate was only $2.0 \%$ for the snails from a pond near Barreiras, using a Bahian strain of S. mansoni and $2.3 \%$ and $1.1 \%$ for snails from Ceará, using a Puerto Rican strain. On the other hand, for the five experiments $\mathbf{B}$. glabrata, the control species, showed an infec tion rate which varied from $78.5 \%$ to $92.1 \%$. 
MALEK, פ. A. \& ROUQUAYROL, M, Z. - Experimental with Schistosoms mansoni of Biomphalaris stramines from different parts of the northeast of Brazil. Rev. Inst. Med. trop. Säo Paulo, 28:160-165, 1986.

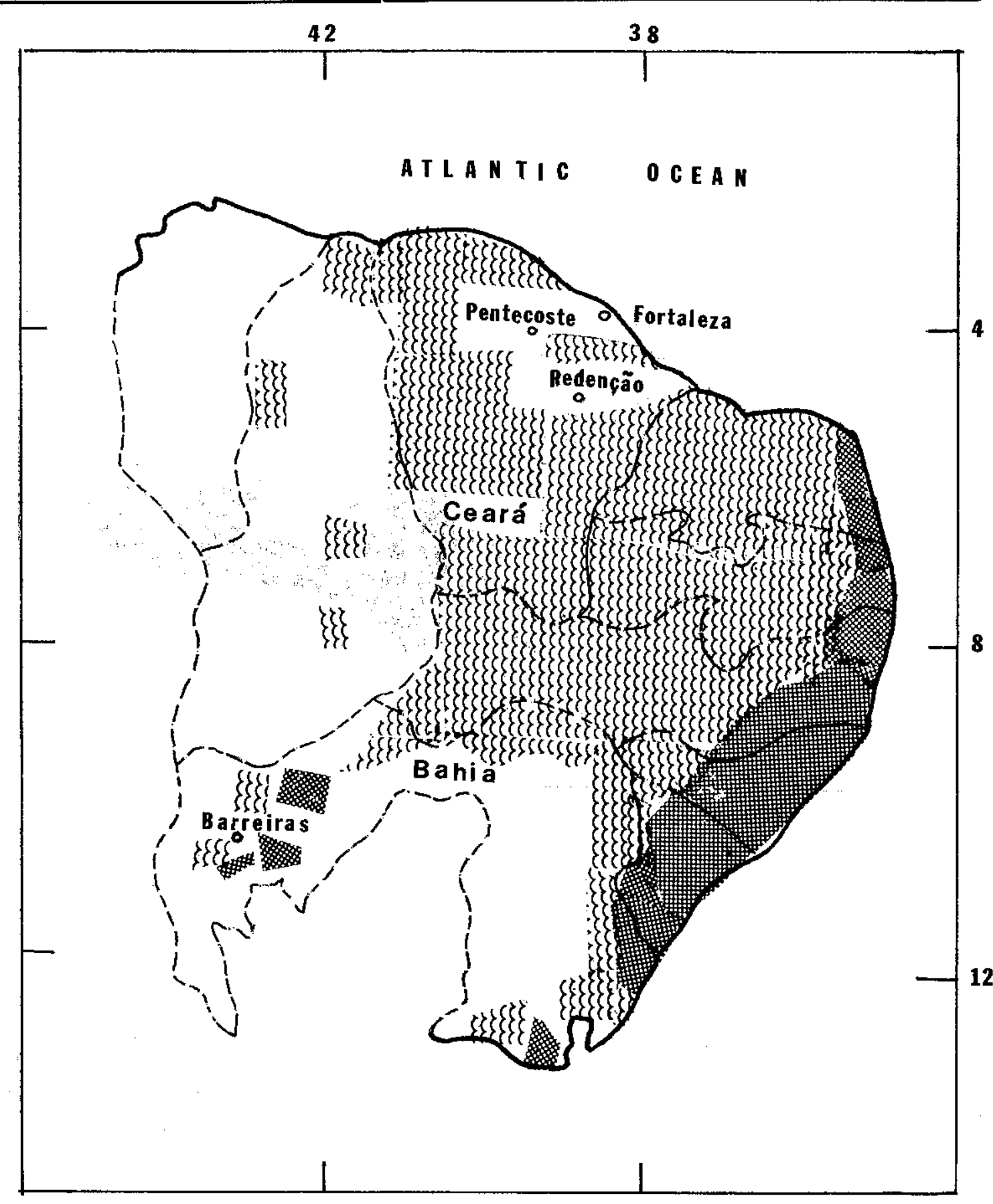

\\{\}\}. Biomphalaria straminea

\section{B. glabrata}

Fig. I - Map of the Northeast of Brazil, showing distribution of Biomphalaria straminea and B. glabrata, and the Iocalities in Ceara and Bahia where collections of snails were made. 
MALEK, E. A. \& ROUQUAYROL, M. Z. - Experimental with Schistosoma mansoni of Biomphalaria stramines from different parts of the northeast of Brazil. Rev. Inst. Med. trop. São Paulo, 28:160-165, 1986.

T A B L E I

Results of exposure of progenies of Biomphalaria stramines from Bahia and ceará, Brazil to miracidia of Schistosoma b

mansoni

\begin{tabular}{|c|c|c|c|c|c|c|c|c|c|}
\hline \multirow{3}{*}{ Locality } & \multicolumn{4}{|c|}{ Biompbalaria stramines } & \multicolumn{4}{|c|}{ B. glabrata (control) } & \multirow{3}{*}{$\begin{array}{l}\text { Strain } \\
\text { of } \mathrm{S} . \\
\text { mansoni }\end{array}$} \\
\hline & \multicolumn{3}{|c|}{ No. snails } & \multirow{2}{*}{$\begin{array}{c}\% \\
\text { infected }\end{array}$} & \multicolumn{3}{|c|}{ No. snails } & \multirow{2}{*}{$\begin{array}{c}\% \\
\text { infected }\end{array}$} & \\
\hline & Exposed & Survived & Infected & & Exposed & Survived & Infected & & \\
\hline \multicolumn{10}{|l|}{ Bahis } \\
\hline SD & 337 & 309 & 9 & 2.9 & $30^{e}$ & 30 & 27 & 89.9 & PR \\
\hline SD & 461 & 420 & 15 & 3.6 & 25 & 24 & 20 & 83.3 & $\mathbf{B A}$ \\
\hline $\begin{array}{c}\text { NB } \\
\text { Ceará }\end{array}$ & \multicolumn{8}{|c|}{ Ceara } & $\mathbf{B A}$ \\
\hline $\mathbf{P}$ & 233 & 217 & 5 & 2.3 & ${ }^{30}$ & 28 & 24 & 85.7 & PR \\
\hline $\mathbf{R}$ & 385 & 352 & 4 & 1.1 & 45 & 42 & 33 & 78.5 & PR \\
\hline
\end{tabular}

Snails of all sizes (ages)

b

Exposure and maintenance temperature, $23-25^{\circ} \mathrm{C}$

c

SD, Sao Desiderio: NB, near Barrixas; P, Pentecoste; R, Redençāo

PR, Puerto Rican, BA, Bahian

Albino NIH strain

$\mathbf{f}$

From stream above reservoir, Săo Desickério, Bahia

\section{DISCUSSION}

Studies on the natural and experimental infection of B. straminea in Ceará are of interest because this biomphalarid species is the only intermediate host of $\mathbf{S}$. mansoni in this part of Brazil. No natural infection with $\mathbf{S}$. mansoni was encountered in the snails collected from Ceara and Bahia, evidently because of the low or moderate human infection rates.

The western area of Bahia (centered around the city of Barreiras, where B. straminea and B. glabrata were collected in this study) is a new distribution record for this part of Brazil. Previously, the two biomphalarid species have been reported only for the eastern (coastal and near-coastal) area of Bahia, along the Atlantic Ocean (PARAENSE 19,20).

In the preseni study experimental exposure of B. straminea from Bahia and Ceará to miracidia of a Puerto Rican strain of $\mathbf{S}$. mansoni to test its susceptibility to this schistosome showed very low infection rates $(1.1 \%$ to $2.9 \%)$. The susceptibility was still low when the snails from Bahia were exposed to a Bahian (Cato landia) strain of the schistosome. A few susceptibility tests by other investigators also yielded low infection rates. BARBOSA \& COELHO ${ }^{3}$ obtained 22 positive snails out of 344 survivors (3.6\%) from Pernambuco; COELHO 9 found two positive snails among 36 survivors $(5.5 \%)$ from Pernambuco; BARBOSA \& FIGUEIREDO ${ }^{\circ}$ found 86 out of 4,206 survivors positive (1.7\%) from Ceará, none from Pentecoste or Redenção; $26 / 1,490$ (1.5\%) from Rio Grande do Norte, and 42/1,527 (2.2\%) from Alagoss; FREITAS et al ${ }^{2}$ found $3 / 500(0.6 \%)$ from Minas Gerais positive; GERKEN et al. ${ }^{13}$ obtained infections in $11 / 1,394(0.79 \%)$ of snails from Lagoa Santa and Lagoa dos Mares, Minas Gerais; and PARAENSE 18 obtained infections in $3 / 28(10.7 \%)$ snails from Amazonas. The above Authors used S. mansoni strains from Pernambuco, Minas Gerais, Pernambuco and Minas Gerais, respectively. Later, SOUZA et al, 22,23 obtained up to $11 \%$ infection when they exposed B. straminea from Minas Gerais to one or more of three strains of S. mansoni from Minas Gerais or São Paulo.

Apparently, the very low susceptibility of B. straminea is correlated with moderate in- 
MALEK, E. A. \& ROUQUAYROL, M. 2. - Experimental with Schistosoma mansoni of Biomphalaria straminea from different parts of the northeast of Brazil. Rev. Inst. Med. trop. Săo Paulo, 28:160-165, 1986.

fection rates with $\mathbf{S}$. mansoni among humans. The prevalence of human schistosomiasis in 1978 was up to $40.1 \%$ in the municipality of Ređenção and up to $20.76 \%$ in the municipality of Pentecoste. These infection rates are based on the results of stool examinations conducted by SUCAM (Superintendencia de Campanhas de Saude Pública) of the Brazilian Ministry of Health, of a moderate or a large sample of the residents in several infected localities in each of the two municipalities in Ceará. For example in the town of Redenção with a population of 3,002 inhabitants, 249 were positive out of 755 examined (32.9\%); in Canta Galo with a population of 601,26 were positive out of 66 examined (39.4\%), and in Barra Nova de Fora with a population of 270,26 were positive out of 53 examined $(6.17 \%)$; in Bairro Ipase with a population of $1,542,115$ were positive out of 554 examined $(20.76 \%)$.

In the municipality of Pentecoste there is a reservoir behind a dam on the river Curu and an irrigation scheme with a complex sys. tem of irrigation canals which, together with the reservoir serve as ideal habitats for B. stra. minea. In 1964 ROUQUAYROL and CANTIDIO found only a $0.7 \%$ infection rate with $\mathbf{S}$. man soni in the valley of the river and called attention to the significance of development of agriculture under irrigation in aggravating the prevalence of schistosomiasis in the area, which has been found to be true on the basis of subsequent examinations (ALENCAR et al ${ }^{2}$ ).

During the senior Author's observations in western Bahia it was noticed that B. straminea competes in certain natural habitats with $\mathbf{B}$. glabrata and usually eliminates the latter species, which shows a much higher natural and experimental susceptibility to infection with $\mathbf{S}$. mansoni. As a result of this competition the two species, in the majority of cases, do not share the same habitat. MICHELSON \& DUBOIS 17 also showed this interspecific competition to occur under laboratory conditions. However, it is unwise to agree with some workers who advocate this competition by B. suraminea as a biological means of controlling populations of the highly susceptible B. glabrata. This is because the poor natural and experimen. tal susceptibility of $\mathbf{B}$. straminea, as demonstrated in the present study, is usually correlat ed with moderate infection rates of schistoso. miasis among the human population. The suggested introduction into a certain waterbody of the competitor snail (B. straminea) would mean the replacement of a highly susceptible species (B. glabrata) by another species, B. stra. minea, which is still an effective transmitter of the disease, despite its very low susceptibility to infection with S. mansoni.

Among the snail hosts of other human species of schistosomes, Bulinus (Bulinus) trun. catus, intermediate host of $\mathbf{S}$. haematobium, always shows very low (less than 1\%) natural infection rates in countries of the Middle East (MALEK ${ }^{16}$ ). Like B. straminea, these low infection rates are correlated with moderate or high infection rates with schistosomiasis among humans However, B. (B.) truncatus differs from $B$. strammea in the fact that, in spite of very low natural infection rates, B. (B.) truncatus shows moderate susceptibility in the laboratory, for example between $21.4 \%$ and $39.6 \%$ in the case of a Sudanese strain of the snail when exposed to a Sudanese strain of S. hae. matobium (MATEK ${ }^{15}$ ).

\section{RESUMO}

Infeção experimental com cepas de Schistosoma mansoni, em amostras de Biomphalaria straminea de algumas localidades do Nordeste do Brasil

Na regiăo oeste do Estado da Bahia habitam caramujos das espécies Biomphalaria gıa brata e B. straminea os quais, em geral, não coexistem no mesmo habitat. No Estado do Leara os unicos nospedeiros intermediárıs de Schısiosomi mansoni sāo da espécie B. straminea. Nieste levantamento não foram detectados B. siraminea naturalmente infectados, nem no Ceará e Bahia. Espécimes de B. straminea, tendo $\mathbf{B}$. glabrata como controle, foram utilizados experimentalmente a fim de se determinar sua suscetibilidade frente a amostras portorriquenhas de S. mansoni. Os referidos B. straminea mostraram baixa suscetibilidade apresentando as seguintes taxas de infecção: $1,1 \%$ den tre os caramujos de Redenção-Ceará; 2,3\% naqueles provenientes de Pentecoste-Ceará e 2,9\% dentre os espécimes colectados em S. Desidério na Bahia. O lote controle, B. glabrata amostra NIH, apresentou elevadas taxas de in- 
MALEK, E. A. \& ROUQUAYROL, M. Z. - Experimental with Schistosoma mansoni of Biomphalaria stxaminea from different parts of the northeast of Brazil. Rev. Inst. Med. trop. Säo Paulo, 28:160-165, 1986.

fecção frente àquela amostra de $\mathbf{S}$. mansoni. Além desta cepa portorriquenha utilizouse tam. bém uma cepa bahiana de $\mathbf{S}$. mansoni cujo teste experimental com B. straminea de São Desidério também demonstrou baixas taxas de infecção, numa média de $3,6 \%$. Aparentemente, a baixa suscetibilidade de $\mathbf{B}$. straminea ao $\mathbf{S}$. mansoni, a despeito da elevada densidade destes caramujos, está em correlação com a prevalência de esquistosomose nas muito elevada no Ceará como mostram os resultados de levantamentos coproscópicos realizados pela SUCAM.

\section{REFERENCES}

1. ALENCAR, J. E. - A schistosomose no Ceará. Ceará Méd., 20: 12-20, 1940.

2. ALENCAR, J. E.; ROUQUAYROL, M. Z.; FIGUETREDO, J. S. \& BEZERRA, O. F. - A esquistossomose no Cesrá, análise do problema atual e sugestóes para o combate. Rev. bras. Malar., 30: 99-121, 1978.

3. BARBOSA, F. S. \& COELHO, M. C. - Qualidades de vector dos hospedeiros de Schlstosoma mansoni no nordeste do Brasil. I. Susceptibllidade de A. glabratus e T. centimetralis a infestação por S. mansoni. Publ. Av. Inst. Aggeu Magalhães, 3; 55-62, 1954.

4. BARbOSA, F. S. \& COELAHO, M. G. - Alguns aspectos epidemiológicos relacionados com a transmissão da es. quistossomose em Pernambuco, Brasil. Publ, Av. Inst. AgEeu Magalhăes, 5: 31-47, 1956.

5. BARBOSA, F. S.; DOBBIN, J. E. \& VIEIRA, A. E. Inquérito preliminar sobre infestaçăo de planorbídeos em alguns municipios de Pernembuco. Publ. Av. Inst. Aggeu Magalhães, 1: 99-124, 1952.

6. BARBOSA, F. S. \& FIGUEIREDO, T. - Susceptibility of the snail intermediate hosts of schistosomiasis from northeastern Brazil to the infection with Schistosoma mansoni. Rev. Inst. Med. trop. S. Paulo, 12: 198-206, 1970.

7. BARBOSA, W.: AZEVEDO, C. D.; SILVA, S. A. H. \& CUNHA, A. - Estado atual da esquistossomose mansỏnica em Goiás. Rev. Soc. bras. Med. trop., 1: 188-195, 1967.

8. BEZERRA, O. F. - Contribuiçăo ao conhecimento dos planorbideos do Estado do Cearḱ. Rev. bras. Malar., 7: $351-355,1955$.

9. COELHO, M. C. - Suscetirilidade de Australorbis tenagophilus a infecçāo por Schistosoma mansont. Rev. Inst. Med. trop. S. Paulo, 4: 289-295, 1962.

10. COELHO, M. C. \& BARBOSA, F. S. - Qualidades de vetor dos hospedeiros de Schistosoma mansoni no nordeste do Brasil. III. Duraçāo da infestaçāo e eliminaçāo de cercárias em Tropicorbis centimetralis. Publ. Av. Inst. Aggeu Magalhães, 5: 21-29, 1956.

11. COUTINHO, B.; GOUVEA, L. \& LUCENA, D. - Investigaçōes em torno da epidemiologia da esquistossomose mansônica em Pontesinha e Victória, Estado de Pernambuco, Brasil. In: MAGALHAES, A. et al. - Esistudos sobre a esquistossomose em. Pernambuco, Brásil. Mem. Inst. Osw. Cruz, 35: 207-230, 1940.

12. FREITAS, J. R.; JUNQUEIRA, D. V. \& GERKEN; $s$ E. - Habitats primitivos de hospedeiros do Schistoso. ma mansonf da regiāo de Lagoa Santa, Minas Gerais. Ciêne. e Cult., 24 (suppl.): 377, 1972.

13. GERKEN, S. E.; ARAUJO, M. de P. T. \& FREITAS, J. R. - Susceptibilidade da Biomphalaria straminea de regiāo de Lagoa Santa (MG) ao Schistosoma mansoni. Rev. Inst. Med. trop. S. Paulo, I7: 338-343, 1975.

14. LUCENA, D. T. - Planorbídeos transmissores da esquistossomose no Nordeste do Brasil. J. hras. Med. 8: $269-276,1964$.

15. MALEK, E. A. - Natural and experimental infection of some bulinid snails in the Sudan with Schistosoma haematobium. In: INTERNATIONAL CONGRESSES ON TROPICAL MEDICINE AND MALARIA, 6., Lisbon, 1058. Proceedings. Porto, Imprensa Portuguesa, 1959, v. 2 , p. 43.52

16. MALEK, E. A. - Bilharziasis control in pump schemes near Khartoum, Sudan and an evaluation of the efficacy of chemical and mechanical barriers. Bull. Wld. Flth. Org., 27: 41-58, 1962.

17. MICHELSON. E. H. \& DUBOIS, L. - Competitive interaction between two snail hosts of Schistoosma mansoni: laboratory studies on Biomphalaria glabrata and B. stramines. Rev. Inst. Med. trop. S. Paulo, 21: 246-253, 1979 ,

18. PARAENSE, W. L. - Moluscos planorbídeos da Ama zonia. Atas do Slmpósio sobre a Biota Amazonica, 3 (Limnologia): 187.194, 1967.

19. Paraense, w. L. - Planorbídeos hospedeiros intermediários do Schistosoma mansoni. In: CUNHA, A. S. da, org. - Esquistossomose mansoni. São Paulo, Sarvier; EDUSP, 1970. Cap. 2, p. 13-30.

20. PARAENSE, W. L. - Distribuiçăo geográfica dos vetores da xistosomose no Nordeste do Brasil. In: CONFERENCIA NACIONAL DE SAÚdE, 6., Brasília, 1977. Anals. Rio de Janeiro, Seçâo de Artes Gráficas da FSESP, 1978. p. 311-315.

21. ROUQUAYROL, M. S. \& CANTIDIO, W. M. - Focos esquistossomóticos potenciais. I. Esquistossomose e outras enteroparasitoses no vale do Curu-Ceará. Rev. Fac. Med. Univ. Ceará, 4: 53-73, 1964.

22. SOUZA, C. P.; RODRIGUES, M. de S. \& ARAUJO, N. - Suscetibilidade de Biomphalaria straminea (Dunker, 1848) de Belo Horizonte (MG) a infecção por cepas de Schistosoma mansoni. Rev. Inst. Med, trop. S. Paulo. 23: $188.193,1981$.

23. SOUZA, C. P.; RODRIGUES, M. de S.; AZEVEDO, $M$ de L. L. \& ARAUJO, N. - Suscetibilidade de populaçōes de Biomphalaria straminea (Dunker, 1848) de Minas Gerais, a infecção por Schistosoma mansonl. hev. Inst. Med, trop, S. Paulo, 23: 212-216, 1981.

Recebido para publicação em 23/7/1985. 